\title{
A Study on the influence of MM.106 rootstock on the Vegetative growth and Leaf mineral content of different apple cultivars
}

\author{
Kebede Jobir, Behailu Asrat and Andargachew Detebo \\ Arba Minch University College of Agricultural Sciences, Department of Horticulture, Ethiopia
}

\begin{abstract}
Effect of MM.106 rootstock on vegetative growth and leaf mineral contents of different apple cultivars (Crispin, Golden delicious, Jonagored and Royal gala) was studied at the Highland Fruits and Vegetables Research Center of Arba Minch University, Gircha, Ethiopia. The research design used was a complete randomized block consisted of four treatments (cultivars) with three replications of 5-tree/ plots. In this trial, total plant height, trunk diameter, leaf area, number of branches and effect of rootstock on the leaf nutrient accumulation of nitrogen, phosphorus, potassium, calcium and magnesium was measured. The maximum vegetative growth was recorded for Crispin followed by Royal gala while Golden delicious showed least growth. MM.106 rootstock absorption and translocation to the grafted cultivars differs. The highest leaf nitrogen content was recorded for Crispin and the greatest amount of potassium accumulation was found in the leaves of Jonagored cultivar.
\end{abstract}

Key words: Apple rootstock, scion cultivar, vegetative growth, nutrient absorption.

\section{Introduction}

Rootstocks influenced the leaf nutrient accumulation of apple cultivars and the differences among the rootstock-scions were attributed to mineral uptake capacity of rootstocks due to their changing root structure (Abrisqueta et. al.,2011). They further reported that, rootstock-scion relations affect the vegetative growth by influencing the nutritional status and adaptation ability of scion to changing environment. Plant nutrient concentrations may differ even if they are grown in the same conditions (Kacar, 1995). Numerous studies have shown that rootstocks can affect the vegetative growth and scion leaf mineral concentration, flower development, yield and fruit quality of different apple cultivars

(Neeme et al., 2006; Fallahi et al., 2007 b). A number of studies have reported that, different rootstocks induce clear differences in growth vigour and other features of scion cultivars (Wertheim, 1998), influences aspects of fruit quality such as ripening and storability (Lord et al., 1985), mineral composition (Drake et al.,1988) and size (Marini et al., 2002). Rootstocks can markedly affect the vegetative growth of the scions. It has been reported that, rootstocks have significant effect on trunk diameter, plant height, leaf area, number of branches and yield of apple scions (Tahereh et al., 2011). The effect of rootstocks on growth, leaf mineral accumulation and fruit quality has been intensively studied (Zekri, 2000a; Sotiropoulos, 2008). However, the effects of most of the rootstocks studied were not consistent from site to site and varied overtime (Yahya et al., 2004). Thus, scion-rootstock combination is fundamental for optimal growth, nutrient uptake and transport. Rootstock effects occur because each rootstock has a different root growth pattern, which influences nutrient uptake. Therefore, it is unwise to adopt root-stock recommendations from one part of the world to another without a thorough evaluation locally. Since environmental conditions and cultural practices are unique and vary considerably from one area to another, a study was carried out to determine the horticultural adaptability and performance of four commercially important cultivars grown on widely used MM.106 rootstock on a typical soil where Gircha High land fruits and vegetables Research center is located. All over the world, the trend in apple growing is to plant more trees per hectare than in the past. In Ethiopia the intensive apple growing is still in development stage. The establishment of intensive apple orchards has been delayed by lack of adequate information on compatible rootstock -scion combination under soil conditions of Ethiopian. In Gircha (Chencha) one limited factor that hinder apple expansion is lack of adequate studies on types of rootstocks used. In the area about nine different rootstocks were used with no evidences on the scions-rootstocks compatibility. Among the rootstocks grown in the area, this study was conducted to evaluate the effect of MM.106 (semi-dwarf rootstock) on tree growth and leaf mineral accumulation of Crispin, Royal gala, Golden delicious and Jonagored cultivars.'

\section{Materials And Methods}

The experiment was established at the Gircha Highland Fruits and Vegetables Research Centre in one of the Gamo High lands of Chencha district, Southern Ethiopia $\left(6^{0} 19^{\prime} 0^{\prime \prime} \mathrm{N}\right.$ latitude and $37^{\circ} 35^{\prime} 0^{\prime \prime} \mathrm{E}$ longitude with altitude of 3007masl). Soil samples were taken to describe the characteristics of soils from 0-15 and 15-30 $\mathrm{cm}$ depth. Air dried soil samples were gently crushed and passed through a $2 \mathrm{~mm}$ sieve. Particle size distribution 
was determined by the hydrometer method. Soil chemical properties were determined following standard procedures: both $\mathrm{pH}$ and electrical conductivity in 1: 2.5 soil: water suspension, calcium carbonate $(\mathrm{CaCO} 3)$ equivalent by a manometric method. Cation exchange capacity (CEC) and exchangeable bases ( $\mathrm{Ca}, \mathrm{Mg}$ and $\mathrm{K}$ ) were analysed using ammonium acetate extraction procedure (Chapman, 1965). $\mathrm{Ca}$ and $\mathrm{Mg}$ were measured with an atomic absorption spectrophotometer whereas, flame photometer was used to measure $\mathrm{K}$ contents. The total $\mathrm{N}$ was analyzed using the Kjeldahl digestion, distillation and titration method as described by Schuman et al. (1973). Available soil P was analyzed following the procedure of Olsen et al. (1954) extraction method as recommended by Tekalign Mamo et al. (2002) for Ethiopian soils. One year old apple cultivars, Crispin, Jonagored, Royal gala and Golden delicious that had been grafted on MM.106 were planted in the August 2015 which is a rainy cold season under climatic condition of Ethiopia. Planting space used between trees and in the row was $4 \times 4 \mathrm{~m}$. Along the rows weeds were controlled manually, and organic manure was applied twice a year during vegetative period. Trunk diameter was measured at a height of $30 \mathrm{~cm}$ above the soil surface and converted to trunk cross-sectional area (TCSA) following Yahya and Teryl (2004). To determine height of the rootstocks, total length above the ground was measured and number of branches was counted following (Esmaeil et al., 2001) method. A total of 30 fully developed leaves from ten replications were measured and the average leaf area $\left(\mathrm{cm}^{2}\right)$ was recorded. The average of two year vegetative growth parameters of the cultivars under study was analyzed. In order to assess nutritional status of the four different apple cultivars, samples of ten young leaves that were fully expanded near base of current year's growth were collected and dried in an oven at $70^{\circ} \mathrm{C}$ to constant weight. For the determinations of $\mathrm{P}, \mathrm{K}, \mathrm{Ca}$ and $\mathrm{Mg}$ concentrations, $0.5 \mathrm{~g}$ of samples were dry ashed in muffle furnace at $550^{\circ} \mathrm{C}$ for $8 \mathrm{~h}$, and the ash was dissolved in $4 \mathrm{ml} 3 \mathrm{~N} \mathrm{HCl}$ and filled up with distilled water as described in Kucukyumuk and Erdal (2011). Phosphorus contents of samples were determined by vanadate-molybdate colorimetric method of Wantabe and Oleson (1963) as described in Antonio et al. (2005). $\mathrm{Ca}$ and $\mathrm{Mg}$ concentrations were determined using atomic absorption spectrophotometer and $\mathrm{K}$ by flame emission spectrophotometers according to procedure described by Kacar and Inal (2008). Nitrogen concentration in samples was determined according to modified Kjeldahl method in which $0.5 \mathrm{~g}$ sample digested in concentrated $\mathrm{H}_{2} \mathrm{SO}_{4}$ and distilled with $\mathrm{NaOH}(40 \%)$. The ammonium $\mathrm{N}$ was fixed in $\mathrm{H}_{3} \mathrm{BO}_{3}(2 \%)$ and titrated with $0.1 \mathrm{~N} \quad \mathrm{H}_{2} \mathrm{SO}_{4}$ following the procedure described by Kucukyumuk and Erdal (2011)

The experiment was a complete randomized block design and consisted of four treatments (cultivars) with three replications of 5-tree/ plots. The data were subjected to analysis of variance to find out treatment effects and/or interactions between factors. Analysis of variance was carried out using MINITAB statistical package version 14. The mean separation was performed by Duncan's multiple range tests at the level of the significance (LSD at $\mathrm{P}<0.05)$.

\section{Results And Discussion}

The result of measured characteristics of soil profile showed that the orchard is located on a clay loam soil with $\mathrm{pH} 4.8$, containing 13.26 organic matter, $4.45 \%$ soil moisture, $4.47 \%$ of organic carbon, Total Nitrogen $0.51 \%$, potassium 22.84ppm, available Phosphorous $\left(\mathrm{P}_{2} \mathrm{O}_{5}\right) 40.18 \mathrm{ppm}$ and Exchangeable acidity $4.27 \mathrm{meq} / 100$ $\mathrm{g}$ soil. The exchangeable bases were in the order of $\mathrm{Ca}(9.97) \geq \mathrm{Mg}(3.47) \geq \mathrm{K}(0.78) \mathrm{Cmol}(+)$.

Leaf nutrient levels were significantly affected by rootstock and rootstock-scion combinations. Nitrogen is one of the most critical elements in determining vegetative growth and tree vigor. Leaf nitrogen content of all four cultivars grown on MM.106 was significantly different. Among the cultivars, Crispin performed maximum followed by Royal Gala in $\mathrm{N}$ uptake. In contrast, Jonagored cultivar combinations had minimum $\mathrm{N}$ contents within deficiency range while Golden delicious, leaves $\mathrm{N}$ content registerd below the deficiency threshold (2.4-2.6\%) established by Steve et al. (2004) (Tab.1). This could possibly be due to incompatibility of rootstock-scion combination since majority of nutritional roots of MM.106 rootstocks are in upper horizon where soil nitrogen is usually present and bound to soil organic matter ( Alva et al., 2006).

Leaf P contents of both Royal Gala and Crispin cultivar grown on MM.106 rootstock yielded similar high values while Jonagored cultivars uptake significantly smaller P just above the deficiency threshold (0.13$0.33 \%$ ) established by Steve et al. (2004) (Table 1). Golden delicious, showed leaf P level smaller than Jonagored. The Maximum amount $\mathrm{P}$ accumulation was registerd for Royal gala while lowest values was recorded in leaves of Golden delicious cultivars. Tsakelidou et al., (2002) have reported that, effect of rootstocks in absorption and transport of $\mathrm{P}$ to leaves of different cultivars significantly differs.

Crispin and Royal gala were better compared to Jonagored and Golden delicious in P uptake because of the nature of the $\mathrm{P}$ in soil profile and distribution of nutritional roots. Plant available soil $\mathrm{P}$ is more abundant in the upper horizon especially in $0-30 \mathrm{~cm}$ layer, thus the density of nutritional roots in the surface horizon is critical for P nutrition. This study showed that, scion/rootstock combination between Royal gala/ MM.106 in comparison to other apple cultivars was likely to be better for P translocation from root to shoots. However, 
under soil condition of Gircha experimental site MM.106 seems well adapted for cultivars understudy in P uptake and translocation.

Table 1: Effect of MM.106 on leaf mineral composition of different apple cultivars

\begin{tabular}{|l|l|l|l|l|c|}
\hline Cultivar used & $\begin{array}{l}\text { Leaf Nitrogen } \\
(\%)\end{array}$ & $\begin{array}{l}\text { Phosphorous } \\
(\%)\end{array}$ & $\begin{array}{l}\text { Potassium } \\
(\%)\end{array}$ & $\begin{array}{l}\text { Calcium } \\
(\%)\end{array}$ & $\begin{array}{l}\text { Magnesium } \\
(\%)\end{array}$ \\
\hline Crispin & $2.52 \mathrm{a}$ & $0.16 \mathrm{~b}$ & $1.37 \mathrm{c}$ & $1.56 \mathrm{a}$ & $0.43 \mathrm{~b}$ \\
\hline Royal gala & $2.43 \mathrm{~b}$ & $0.21 \mathrm{a}$ & $1.45 \mathrm{~b}$ & $1.37 \mathrm{c}$ & $0.45 \mathrm{a}$ \\
\hline $\begin{array}{l}\text { Golden } \\
\text { delicious }\end{array}$ & $2.17 \mathrm{~d}$ & $0.12 \mathrm{c}$ & $1.25 \mathrm{~d}$ & $1.25 \mathrm{~d}$ & $0.31 \mathrm{~d}$ \\
\hline Jonagored & $2.37 \mathrm{c}$ & $0.15 \mathrm{~b}$ & $1.78 \mathrm{a}$ & $1.53 \mathrm{~b}$ & $0.39 \mathrm{c}$ \\
\hline LSD (0.05) & 0.02 & 0.01 & 0.00 & 0.01 & 0.00 \\
\hline C.V\% & 0.73 & 5.10 & 0.27 & 0.67 & 0.87 \\
\hline
\end{tabular}

Means with the same letter are not significantly different

The rootstock used influenced the leaf $\mathrm{K}$ content of apple cultivars (Table 1) despite leaf $\mathrm{K}$ contents was within the optimum range (1.37-1.78\%) except for Golden delicious which is below the sufficiency range $(1.35-1.85 \%)$ established by Steve et al. (2004). Jonagored was superior over the other cultivars in K uptake and translocation to leaves. Researchers have reported contradictory results that rootstocks had some or no effect on K uptake (Georgiou 2002; Smith et al., 2004); however, this study confirmed significant effects even causing $\mathrm{K}$ deficiency for certain scion/rootstock combinations in accordance to Tsakelidou et al. ( 2002).

The content of calcium in leaves of cultivars on the investigated rootstock was related to the scion/rootstock compatibility and was significantly within the sufficiency range (1.3-2\%) established by Steve et al. (2004) for most of the cultivars under study except Golden delicious which records below the adequate level (Tab. 1). Among the cultivars the highest level of calcium was found in leaves of Crispin followed by Jonagored.

Leaf Mg contents of both Royal Gala and Crispin cultivar grown on MM.106 rootstock yielded significantly similar high values while Golden delicious cultivars uptake significantly smaller Mg just below the sufficiency threshold (0.35-0.50\%) established by Steve et al. (2004) (Table 1). Golden delicious/MM.106 relation revealed weak uptake and translocation of most nutrients compared to other scion rootstock combination under study. Maximum Mg uptake was observed for Jonagored within the sufficiency range and the lowest values were recorded in leaves of Golden delicious cultivar.

Rootstocks effect on characteristics of vegetative growth revealed itself on the third year of growth. The result of variance analysis (Table 2) shows that the diameter size of the scion cultivar was meaningfully different confirmed significant effect of MM.106 on trunk growth of the cultivars. The interaction between rootstock used and scion cultivars had significant effect on trunk diameter. As shown in Table 2, Crispin, Royal gala and Jonagored cultivars had the maximum trunk diameter compared with Golden delicious. Among the cultivars the highest trunk diameter $\left(4.62 \mathrm{~cm}^{2}\right)$ was recorded for Crispin while the lowest $\left(3.13 \mathrm{~cm}^{2}\right)$ was registered for Golden delicious. In this study the scion- rootstock interaction had significant effect on the height of the cultivar. Crispin was found to be the tallest cultivar $(1.73 \mathrm{~m})$ while the shortest was recorded for Golden delicious $(0.98 \mathrm{~m})$.

Table 2: Effect of MM.106 on vegetative growth of different apple cultivars

\begin{tabular}{|l|l|l|l|l|}
\hline Cultivars & $\begin{array}{l}\text { Trunk Circumference } \\
\left(\mathrm{Cm}^{2}\right)\end{array}$ & Height $(\mathrm{m})$ & Number of branches & $\begin{array}{l}\text { Leaf area } \\
\left(\mathrm{Cm}^{2}\right)\end{array}$ \\
\hline Crispin & $4.62 \mathrm{a}$ & $1.73 \mathrm{a}$ & $5.6 \mathrm{a}$ & $25.06 \mathrm{a}$ \\
\hline Royal gala & $4.31 \mathrm{~b}$ & $1.42 \mathrm{~b}$ & $3.8 \mathrm{~b}$ & $23.91 \mathrm{~b}$ \\
\hline Golden delicious & $3.13 \mathrm{~d}$ & $0.98 \mathrm{~d}$ & $2.4 \mathrm{~d}$ & $18.50 \mathrm{~d}$ \\
\hline Jonagored & $4.16 \mathrm{c}$ & $1.05 \mathrm{c}$ & $3.2 \mathrm{c}$ & $21.23 \mathrm{c}$ \\
\hline LSD $(0.05)$ & 0.00 & 0.00 & 0.05 & 0.01 \\
\hline C.V\% & 0.06 & 0.19 & 0.98 & 0.03 \\
\hline
\end{tabular}

The analysis of variance showed that, the rootstock used significantly affect the vegetative growth as was also significant differences between the cultivars (Table 2). Among the cultivars the highest amount of growth was recorded for Crispin cultivar followed by Royal gala, while Jonagored registered intermediate and least was found for Golden delicious. Therefore, this study revealed that, under the soil condition of study site the highest vegetative growth was obtained for scion -rootstock combination of Crispin on MM.106 rootstock while least was recorded for Golden delicious. 


\section{Conclusions}

The effect of MM.106 on vegetative growth and leaf nutrient accumulation of the four cultivars studied were significant. In particular, Royal gala recorded maximum absorption for $\mathrm{P}$ and $\mathrm{Mg}$ followed by Crispin with high potential to accumulate $\mathrm{N}$ and $\mathrm{Ca}$ levels. Among the four cultivars highest $\mathrm{K}$ concentration was found in leaves of Jonagored while Golden delicious registered least accumulation of all nutrients. The highest trunk growth and leaf area was obtained for Crispin followed by Royal gala in contrast to Golden delicious which is least. Thus, under the soil condition of Gircha, in comparison with the other three, the scion-rootstock combination of Golden delicious on MM.106 rootstock showed least performances.

\section{Acknowledgements}

The authors would like to thank Arba Minch University for financial support and Chencha kalehiwot protestant church assistants for their invaluable contributions to this research.

\section{References}

[1] Abrisqueta I, Quezada-Martin R, Munguia-Lopez J, Ruiz-Sanchez M C, Abrisqueta J M \& Vera

[2] J (2011). Nutrient concentrations of peach-tree leaves under deficit irrigation. Journal of Plant Nutrition and Soil Science 174: 8187.

[3] Alva, A. K., S. Paramasivam, A. Fares, T. A. Obreza, and A. W. Schumann. (2006). Nitrogen best management practice for citrus trees. II. Nitrogen fate, transport and components of N budget. Scientia Horticulturae 109: 223-233.

[4] Chapman, H. D. (1965). Cation exchange capacity by ammonium saturation. In: Methods of Soil Analysis Chemical and Microbiological Properties. American Society of Agronomy, Inc., Publisher, Madison, Wisconsin, USA.

[5] Esmaeil, F., Chun, I. J. Gerry, H. N. and Michael, C. W. (2001). Effects of three Rootstocks on photosynthesis, leaf mineral nutrition, and vegetative growth of "BC-2 Fuji” apple trees, Journal of Plant Nutrition. 24: 827-834.

[6] Fallahi, E., Ratnaprabha, R., Tripepi, R., Shafii, B., Fallahi, B.(2007b) Tree growth, yield, fruit quality, and mineral partitioning as affected by rootstock and irrigation methods. Intl. J. Fruit Sci. 7:3-24.

[7] Georgiou, A. 2002. Evaluation of rootstocks for 'Clementine' mandarin in Cyprus. Scientia Horticulturae 93: 29-38.

[8] Kacar B. (1995). Soil Analysis. Ankara University, Faculty of Agriculture. Ankara, Turkey.

[9] Kacar, B., and Inal, A. (2008). Plant Analysis, Nobel Sanz, M., Pascual, J., Machin J., (1997). Prognosis and correction of iron chlorosis in peach trees: Influence on fruit quality. J. Plant Nutrition, 20 (11): 1567.

[10] Kucukyumuk, Z. and Erdal I. (2011). Rootstock and cultivar effect on mineral nutrition, seasonal nutrient variation and correlations among leaf, flower and fruit nutrient concentrations in apple trees. Bulgarian Journal of Agricultural Science 17: 633-641.

[11] Lord, W.J., Greene, D.W. R., Damon, J.R. and Baker, J.H. (1985). Effects of stem piece and rootstock combinations on growth, leaf mineral concentrations, yield and fruit quality of 'Empire' apple trees. J. Amerc. Soc. Hortic. Sci.110: 422-425.

[12] Marini, R. P., Barden, J.A., Cline, J.A., Perry, R. L. and Robinson, T. (2002). Effect of apple rootstocks on average 'Gala' fruit weight at four locations after adjusting for crop load J. Amerc. Soc. Hortic. Sci.127: 749- 753.

[13] Neeme, U., Toivo, U., Krista, T. (2006). Effect of five rootstocks on growth and yield of four apple cultivars in young orchard. Polli horticultural research center of the institute of agricultural and environmental sciences. Estonia University of life sciences. 25 (3):192-198.

[14] Schuman, G.E., Stanley, A.M. and Knudsen, D. (1973). Automated total nitrogen analysis of soil and plant samples. Proc. Soil Sci. Soc. Amer. 37:480-481.

[15] Steve H., Mike F., and Kevin I. (2004). Diagnosing Apple Tree Nutritional Status: Leaf Analysis Interpretation and Deficiency Symptoms. New York Fruit Quarterly.

[16] Sotiropoulos, T. E. (2008). Performance of the apple (Malus domestica Borkh) cultivar Imperial

[17] Double Red Delicious grafted on five rootstocks. Hort. Sci. (Prague). 35 (1): 7-11.

[18] Tekalign Mamo, Christian, R., and Burkhard, H. (2002). Phosphorus Availability Studies on Ten

[19] Ethiopian Vertisols. Journal of Agriculture and Rural Development in the Tropics and Subtropics 103 (2) $177-183$.

[20] Tsakelidou, K., X. Papanikolaou, and E. Protopapadakis (2002). Rootstock effects on the yields, tree and fruit characteristics of the mandarin cultivar 'Clementine' on the Island of Rhodes. Experimental Agriculture 38: 351-358.

[21] Wertheim, S.J. (1998). Rootstock Guide. Brugstraat 51, 4475 AN Wilhelminadorp, the Netherlands.

[22] Yahya, R. Al-Hinai and Teryl, R. R. (2004). Rootstock Effects on Growth and Quality of Gala Apples. Hortic. Sci. 39(6): 1231-123.

[23] Zekri, M. (2000a). Citrus rootstocks affect scion nutrition, fruit quality, growth, yield and economical return. Fruits 55:231-239. 